\title{
The Atlantic Ocean at the Last Glacial Maximum: 1. Objective Mapping of the GLAMAP Sea-Surface Conditions
}

\author{
C. Schäfer-Neth* and A. Paul \\ DFG Forschungszentrum Ozeanränder, Universität Bremen, Postfach 3304 40, \\ 28334 Bremen, Germany \\ *corresponding author(e-mail): csn@uni-bremen.de
}

\begin{abstract}
Recent efforts of the German paleoceanographic community have resulted in a unique data set of reconstructed sea-surface temperature for the Atlantic Ocean during the Last Glacial Maximum, plus estimates for the extents of glacial sea ice. Unlike prior attempts, the contributing research groups based their data on a common definition of the Last Glacial Maximum chronozone and used the same modern reference data for calibrating the different transfer techniques. Furthermore, the number of processed sediment cores was vastly increased. Thus the new data is a significant advance not only with respect to quality, but also to quantity. We integrate these new data and provide monthly data sets of global sea-surface temperature and ice cover, objectively interpolated onto a regular $1^{\circ} \times 1^{\circ}$ grid, suitable for forcing or validating numerical ocean and atmosphere models. This set is compared to an existing subjective interpolation of the same base data, in part by employing an ocean circulation model. For the latter purpose, we reconstruct sea surface salinity from the new temperature data and the available oxygen isotope measurements.
\end{abstract}

\begin{abstract}
Aims of this study
Until very recently, ocean-wide - and even more so global - reconstructions of glacial sea-surface conditions suffered from severe limitations:

- Data scarcity: Except for the pioneering CLIMAP (1981) study, all data sets were confined to small areas of the ocean, and the number of sediment cores was relatively small. For example, the reconstruction of Weinelt et al. (1996) was limited to the northeastern part of the Atlantic Ocean and employed only 25 cores with temperature data. - Chronozone definition: Depending on the type of sediment core data measured by the different groups, the chronozone of the Last Glacial Maximum (LGM) within the core could be identified using a $\delta^{18} \mathrm{O}$ criterion, ${ }^{14} \mathrm{C}$ datings, the minimum of reconstructed SST as in CLIMAP, lithological parameters, and other evidence. Thus, at the small scale, even cores in close vicinity could easily yield "LGM" SSTs belonging to considerably different times and introduce unrealistic high variability into

any field interpolated horizontally from the core data. At the large scale, data sets provided by different institutions for different parts of the ocean could not be consistently combined due to offsets between them.

- Methodology: SST estimates may be derived from different proxy data, such as faunal assemblages of foraminifera and dinoflagellates, alkenone concentrations, oxygen isotopes, and more. Results from different proxies are not equivocal. For example, tropical and subtropical SST estimates from alkenones and corals sampled from the western Atlantic Ocean are lower than SSTs derived from faunal assemblages (Guilderson et al. 1994; Rühlemann et al. 1999; Crowley 2000). Reconstructions of glacial land temperatures (Rind and Peteet 1985; Stute et al. 1992; Aeschbach-Hertig et al. 2000; Aeschbach-Hertig et al. 2002) too indicate that the assemblage-based SSTs are in part too high.
\end{abstract}


- Calibration: Regardless of the method used, it has to be calibrated using the modern relations between SST and the respective proxy. Any change of the modern reference data set will alter the calculated paleo-SSTs. Quite commonly, the atlas by Levitus (1982) and, more recently, the WOA 1994 data set (Levitus and Boyer 1994) have been employed. Increasing the differences further, for some studies the surface values were taken, whereas others were based on the temperatures from 10 meters depth, or a vertical average over the upper 50 meters. In addition, some groups used local data sets with higher spatial resolution that were more appropriate for the region studied than the global compilations (e.g. De Vernal et al. 2000).

All these differences cause inconsistencies between SST reconstructions at individual sediment core sites that make interpolation over a larger region a difficult if not impossible task. However, a reliable and consistent set of sea-surface conditions is still a necessity for driving and validating numerical models of paleoclimate. Being aware of this, a number of the institutions contributing paleo-temperature reconstructions (Table 1) succeeded to ground their reconstructions on a common base, that is, a uniform definition for the LGM chronozone and a standardized set of modern reference data. This cooperation greatly improved both quality and quantity of the SST estimates, and gave an opportunity to produce new, and better, seasonal maps of glacial SST on a regular grid. We realize that the supplemental data we used to fill in the remaining void areas (Table 2) do not fully comply with the new standards. However, we carefully checked these data for inconsistencies with the GLAMAP sets, both in the selection process and by variogram analysis.

\section{Improved LGM SST and SSS Data}

The joint effort of the contributing research groups aimed at reducing the discrepancies between individual SST reconstructions and filling the still large undersampled areas of the ocean. Many of the hindrances mentioned in the introduction were overcome within the last few years, at least for the Atlantic Ocean:

- The number of sampled and analyzed sediment cores was vastly increased. Instead of typically some ten or twenty cores per group, now there are nearly 300 SST reconstructions available for the Atlantic ocean (Fig. 1, top), fairly exceeding all previous studies, even CLIMAP (1981) with its almost 180 cores on the global scale. These point-wise data is supplemented by Summer and Winter sea-ice reconstructions for both hemispheres.

- It was agreed on two only slightly different definitions for the LGM: the GLAMAP chronozone (Sarnthein et al. 2003a) between 18000 and 22000 calendar years before present, based on the maximum $\delta^{18} \mathrm{O}$ values in the cores, and the EPILOG chronozone (Mix et al. 2001) from 19000 to 23000 years, defined using the minimum glacial sea level. Thus, both definitions overlap in the time interval of 19-22 ka, and SST estimates for both chronozones differ only marginally at a given core location (Pflaumann et al. 2003; Gersonde et al. 2003; Niebler et al. 2003). In fact, both chronozones are subsets of the slightly broader EPILOG level 2

\begin{tabular}{|c|c|c|c|c|}
\hline Region, Season, Depth & Organisms $^{1}$ & Method $^{2}$ & $\mathrm{Age}^{3}$, ka BP & Authors \\
\hline \multicolumn{5}{|c|}{ SST } \\
\hline South Atlantic, February, $10 \mathrm{~m}$ & F R D & TF MAT & $23-19$ & $\begin{array}{l}\text { Gersonde et al. 2003; } \\
\text { Niebler and Gersonde 1998; } \\
\text { Abelmann et al. 1999; } \\
\text { Zielinski et al. 1998; }\end{array}$ \\
\hline South to tropical Atlantic, annual mean / seasonality, $10 \mathrm{~m}$ & $\mathrm{~F}$ & TF & 23-19 & Niebler et al. 2003 \\
\hline Tropical to North Atlantic, Jan-Mar / Jul-Sep, 10 m & $\mathrm{F}$ & SIMMAX & $22-18$ & Pflaumann et al. 2003 \\
\hline \multicolumn{5}{|c|}{ Ice Cover } \\
\hline South Atlantic, August & D & A & 23-19 & $\begin{array}{l}\text { Gersonde et al. 2003; } \\
\text { Gersonde and Zielinski } 2000\end{array}$ \\
\hline North Atlantic, Jan-Mar / Jul-Sep & \multicolumn{2}{|c|}{ via SST } & $22-18$ & Pflaumann et al. 2003 \\
\hline
\end{tabular}

Table 1. GLAMAP data employed for this study. 


\begin{tabular}{|c|c|c|c|c|c|}
\hline \multicolumn{2}{|c|}{ Region, Season, Depth } & Organisms $^{1}$ & Method $^{2}$ & $\mathrm{Age}^{3}, \mathrm{ka} \mathrm{B}$ & Authors \\
\hline \multicolumn{6}{|c|}{ SST } \\
\hline \multicolumn{2}{|c|}{ North Atlantic, February / August, 0 m } & Dc & MAT & $23-19$ & De Vernal et al. 2000 \\
\hline \multicolumn{2}{|c|}{ Atlantic, February / August, $0 \mathrm{~m}$} & $\mathrm{~F}$ & MAT & $18^{14} \mathrm{C}$ & Prell 1985 \\
\hline \multicolumn{2}{|c|}{ Mediterranean, February / August, 0 m } & $\mathrm{F}$ & TF & $18^{14} \mathrm{C}$ & Bigg 1994 \\
\hline \multirow{2}{*}{\multicolumn{2}{|c|}{ Global Ocean, February / August, 0 m }} & F R D C & TF & $18^{14} \mathrm{C}$ & CLIMAP 1981 \\
\hline & & \multicolumn{4}{|c|}{ Ice Cover } \\
\hline \multicolumn{2}{|c|}{ North Atlantic, February / August } & Dc & MAT & $23-19$ & De Vernal et al. 2000 \\
\hline \multirow{2}{*}{\multicolumn{2}{|c|}{ Global Ocean, February / August }} & F R D C & TF & $18^{14} \mathrm{C}$ & CLIMAP 1981 \\
\hline & & \multicolumn{4}{|c|}{ Planktic foraminiferal $\delta^{18} O$} \\
\hline South Atlantic & \multicolumn{5}{|c|}{ Melles 1991; Duplessy et al. 1996} \\
\hline North Atlantic & \multicolumn{5}{|c|}{$\begin{array}{l}\text { Kellogg et al. 1978; Ruddiman and McIntyre 1981; Jansen and Erlenkeuser 1985; Zahn et al. 1985; } \\
\text { Bard et al. 1987; Morris 1988; Jones and Keigwin 1989; Keigwin and Boyle 1989; Jansen and Veum 1990; } \\
\text { Vogelsang 1990; Duplessy et al. 1991; Lackschewitz 1991; Veum et al. 1992; Duplessy et al. 1992; } \\
\text { Köhler 1991; Jünger 1993; Weinelt 1993; Sarnthein et al. 1995; Weinelt et al. } 1996\end{array}$} \\
\hline \multicolumn{6}{|c|}{$\begin{array}{l}\text { Notes on Table } 1 \text { and } 2 \text { : } \\
{ }^{1} \text { F: Foraminifera, R: Radiolaria, D: Diatoms, C: Coccolithophores, Dc: Dinocysts. } \\
2 \text { TF: Transfer functions, MAT: Modern analog technique, SIMMAX: revised MAT with distance weights (Pflaumann et al. 1996), } \\
\text { A: Abundance. } \\
{ }^{3} \text { Calendar ages, if not marked as }{ }^{14} \mathrm{C} \text {. } \\
{ }^{4} \text { Average sea-ice curve. }\end{array}$} \\
\hline
\end{tabular}

Table 2. Supplemental data collected for this study.

chronozone between 18000 and 24000 years (Mix et al. 2001).

- For the modern reference data set, the WOA 94 (Levitus and Boyer 1994) temperature at 10 meters depth was chosen.

- These new definitions for chronozone and reference data set were not only applied to newly sampled sediment cores, but older census counts were re-evaluated under the new settings.

To show how significant these improvements are, we compare geostatistical analyses of modern and glacial SST data sets (Fig. 2). The top panel illustrates the benefits of the common chronozone definition and modern reference data. Between $50^{\circ} \mathrm{N}$ and $80^{\circ} \mathrm{N}$, the data available in 1994 (Schulz 1994) exhibit high variances at small distances (dashed line). This is in contrast to the spatial dependencies of modern temperatures (shaded), which show low variance at short distance, as expected. To obtain this variogram, we used only the WOA 98 temperatures sampled at the positions of the 15 '94 SST reconstructions. With the advent of the new GLAMAP data, the situation has been improved substantially (solid line). Even taking only the data for the '94 locations yields a much more reasonable variogram, indicating similar values at close distance, and growing differences as distance increases. In the same manner, the data quality was improved in the South Atlantic Ocean (middle panel). As can be seen from the coincindent peaks of the two variograms from the South Atlantic Ocean, sampling density is also an important factor. Using the full GLAMAP data set between $50^{\circ} \mathrm{N}$ and $80^{\circ} \mathrm{N}$ (lower panel, shaded) yields a much smoother variogram that is more suitable for fitting and gridding than the variogram (solid line) that is obtained if the same data is reduced to the ' 94 sites. However, the main advance is the careful refinement of the criteria for including core samples into the LGM reconstruction, and how to calibrate the transfer technique. The underlying methods and proxies to determine SST are still different throughout the research groups (Table 1).

\section{$S S T$}

The SST reconstructions employed for the present study are listed in Tables 1 and 2 and are described in detail by Paul and Schäfer-Neth (2003) - termed PSN hereafter. To compile our new Atlantic-wide 


\section{Glacial Sea Surface Temperature from Sediment Cores}
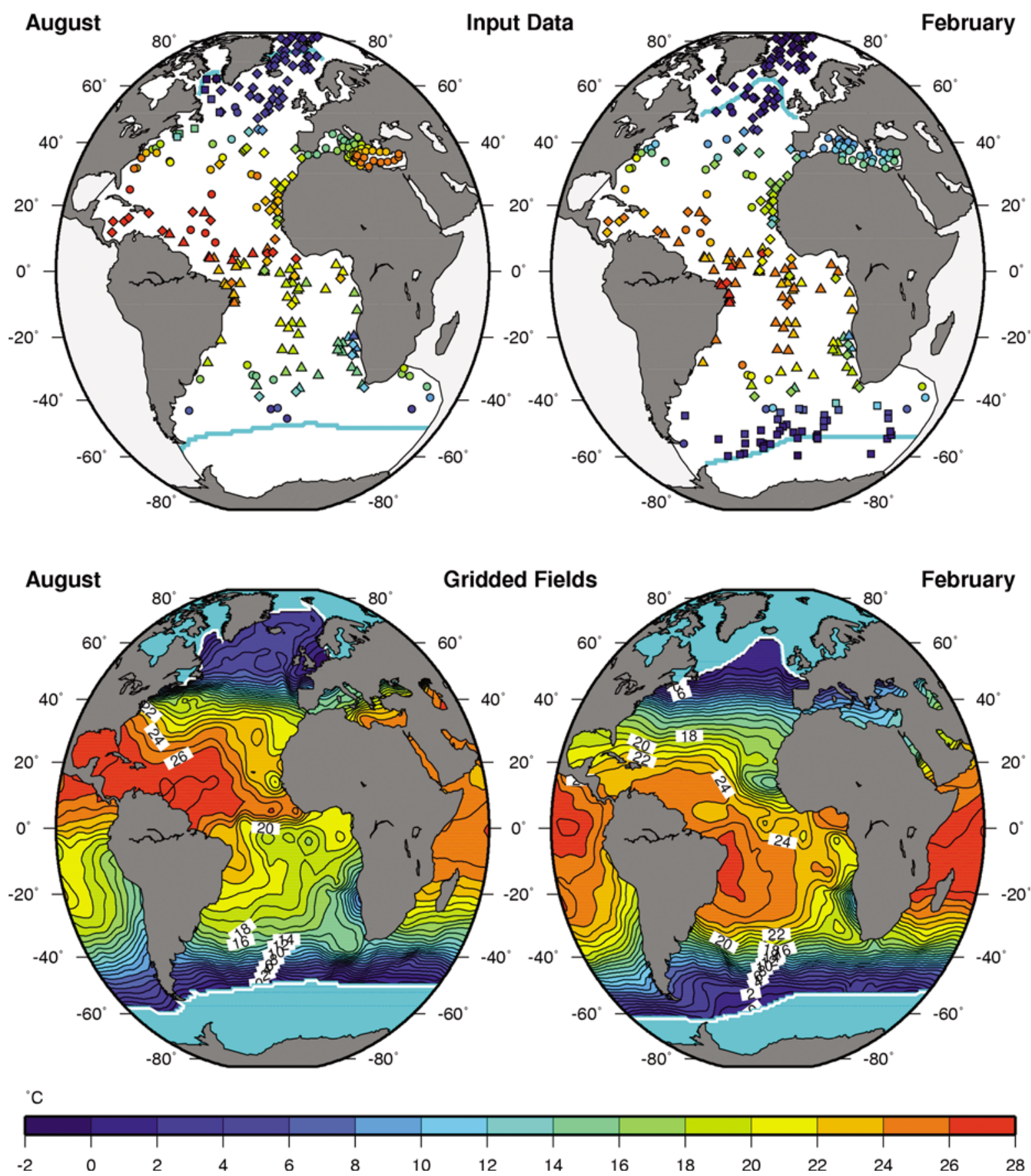

Fig. 1. Glacial sea-surface temperature $\left({ }^{\circ} \mathrm{C}\right)$. Top row: Data base. Triangles: Niebler et al. 2003. Diamonds: Pflaumann et al. 2003. Boxes: De Vernal et al. 2000 (Aug), Gersonde et al. 2003 (Feb). Circles: Prell 1985 (Atlantic), Bigg 1994 (Mediterranean). Blue lines: Ice edges after Pflaumann et al. 2003; De Vernal et al. 2000; Gersonde and Zielinski 2000. Light grey shade: SST data taken from CLIMAP (1981). Bottom row: Resulting $1^{\circ} \times 1^{\circ}$ gridded fields, white lines denote ice edge. 

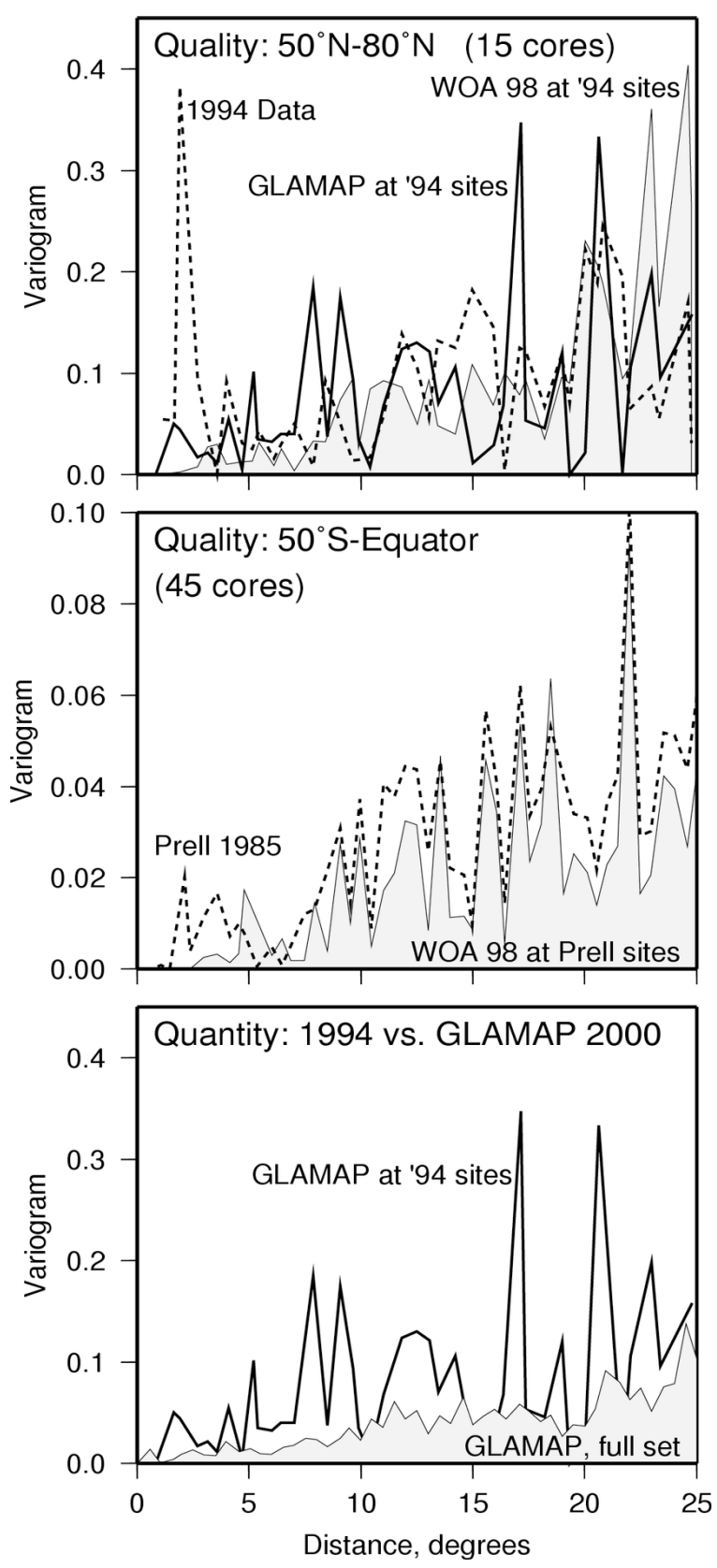

Fig. 2. Empirical variograms employing different presentday and glacial data sets of boreal summer SSTs. Top panel: Effect of the refined chronozone definition and calibration for the North Atlantic Ocean: results for the data available in 1994 (dashed, Schulz 1994) and for the GLAMAP (solid) and WOA 98 (shaded) data at the same core locations. Middle: Like above, but for the South Atlantic Ocean: results from the Prell (1985) data set (dashed) compared to the WOA 98 data (shaded) sampled at the same core sites. Bottom: Effect of the inclusion of new SST estimates: GLAMAP at the 1994 core sites (solid) compared to the full GLAMAP set. gridded SST fields, we used the following GLAMAP reconstructions:

- The austral summer SSTs from the Atlantic sector of the Southern Ocean by Gersonde et al. (2003), based on faunal assemblages of foraminifera (Niebler and Gersonde 1998), radiolaria (Abelmann et al. 1999), and diatoms (Zielinski et al. 1998).

- The seasonal SSTs computed from the annual means and seasonalities reconstructed by Niebler et al. (2003) for the South Atlantic Ocean.

- The seasonal SSTs for the North Atlantic Ocean estimated by Pflaumann et al. (2003).

Since these new data do not cover the Atlantic Ocean and its marginal seas as a whole, we included the following earlier reconstructions after carefully checking for possible inconsistencies with the GLAMAP data:

- The August summer SSTs for the North Atlantic Ocean derived by De Vernal et al. (2000) from assemblages of dinoflagellate cysts. In the northeastern Atlantic, these SSTs seem unrealistically high, in part even higher than modern temperatures. There are two conceivable causes for this: First, the high SST may indicate a very shallow, light surface layer produced by summer ice melt that is rapidly warmed to these high values. Second, there might be advection of warmer water from lower latitudes. Both scenarios would be accompanied by a strong stratification near the sea surface, leading to differences between temperatures reconstructed from the shallow-dwelling dinoflagellates and the foraminifers dwelling at greater depth. Since the northeastern Atlantic Ocean is well covered by GLAMAP, we did not use the reconstructions of De Vernal et al. (2000) for this area.

- The revised seasonal CLIMAP SSTs by Prell (1985) in the western parts of the Atlantic Ocean and east of South Africa.

- The seasonal SSTs for the Mediterranean Sea as compiled by Bigg (1994) from the reconstructions by Thiede (1978) and Thunell (1979).

- The seasonal CLIMAP (1981) data for the western part of the Mexican Gulf.

However, there are a number of significant differences between the interpolated SST fields of our previous study and those presented here. Most important, the data by Pflaumann et al. (2003) ex- 
ists in two versions, namely the original core-based pointwise SSTs, and as part of a map of isolines that were constructed based on a subjective interpolation of their own and the Niebler et al. (2003) data. It was this second version we used in our earlier study (PSN).

Despite the advances in data quality that have been demonstrated above, there are still sediment cores that are located closely to each other but nevertheless show considerable differences between the reconstructed temperatures. When interpolating such data by hand, some decision has to be made as to whether take some sort of a mathematically strict average, discard less reliable estimates, include some prior knowledge from other proxy data, or even honor the best-sampled core as the single representative one. Here we investigate the differences between these subjectively interpolated data and an objective interpolation of the core-based SST. In our earlier study, we had to employ additional tie points where the isolines ended in the open ocean to avoid artificial fronts between these ends and the ocean margins. This was not necessary anymore. Furthermore, using now the core-based SSTs only, we did not include the reconstructed ice edges in the gridding process. Instead, SSTs were interpolated 'as is', and the ice covers were superimposed onto the gridded fields.

Like in our previous study, we used variogram analysis and kriging for interpolation of the SSTs. This was done with spherical-coordinate versions (Schäfer-Neth et al. 1998) of the gamv2 and okb2d routines of the GSLIB package (Deutsch and Journel 1992). To account for changing spatial variabilities between the different regions of the Atlantic Ocean, we divided each of the monthly sets into 10 latitude belts 30 degrees wide, each overlapping the next by 15 degrees, and calculated five experimental variograms, one omnidirectional and four in the local meridional, zonal, SW-NE, and SENW directions, the latter four with an angular tolerance of 45 degrees. Lag spacing was set to a maximum of 50 lags of 2 degrees. The kriging was carried out for each belt on a regular $1^{\circ} \times 1^{\circ}$ grid using variogram models fitted to the pair of perpendicular variograms showing maximum and minimum variance. In cases of small overall variance, the omnidirectional variograms were used. Joining the overlapping belt-wise grids by weighted averaging and merging with the global CLIMAP (1981) data sets with an additional $2^{\circ}$ moving average yielded the new August and February SST fields (Fig. 1, bottom row). Following the PMIP (1993) guidelines, we constructed a seasonal cycle by first fitting a sinusoidal cycle to the glacial-to-modern anomalies and then adding the modern monthly SSTs (10 m values from WOA 1998).

\section{Ice Cover}

In addition to the SST estimates, there are reconstructed August and February ice edges for the Atlantic Ocean (Tables 1 and 2) In the Southern Hemisphere, Gersonde et al. (2003) and Gersonde and Zielinski (2000) derived maximum and average sea-ice extents during austral winter from diatom abundances. For our compilation, we used their average winter curve. Within $2^{\circ}-3^{\circ}$ of latitude, this line corresponds to the line of maximum ice advance by Crosta et al. (1998), except that it indicates a little more ice in the western, but somewhat less ice in the eastern South Atlantic Ocean. The ice extent during glacial austral summer is less well constrained (Gersonde et al. 2003). However, these authors suggest an ice edge north of its position during modern summer in the western, but close to modern winter conditions in the eastern Atlantic Ocean. We therefore chose a line starting at $64^{\circ} \mathrm{S}$ in the Drake Passage and reaching $62^{\circ} \mathrm{S}$ south of Africa. The ice edge lines for the South Atlantic Ocean were smoothly joined to the CLIMAP (1981) ice edges in the Pacific and Indian Oceans. Based on a correlation of modern sea-ice extent and SST estimated from core-top foraminifer assemblages, Sarnthein et al. (2003b) placed the summer and winter ice edges along the $3^{\circ} \mathrm{C}$ and $0.4^{\circ} \mathrm{C}$ SST isolines in the northeastern Atlantic Ocean. We extended these reconstructions to the west according to the lines derived from dinoflagellate cyst assemblages by De Vernal et al. (2000). From these minimal and maximal ice covers, we constructed five additional monthly ice cover fields, gradually migrating between the two extremes and setting SST to $-1.8^{\circ} \mathrm{C}$ in the ice-covered regions. 


\section{SSS}

We estimated sea-surface salinity (SSS) following the approach of Schäfer-Neth (1998) and SchäferNeth and Paul (2001) by first computing the sea water oxygen isotope ratio $\delta^{18} \mathrm{O}_{\mathrm{w}}$ from the newly gridded temperature and the carbonate isotopic composition $\delta^{18} \mathrm{O}_{\mathrm{C}}$ of fossil foraminifer shells, and then calculating SSS from $\delta^{18} \mathrm{O}_{\mathrm{w}}$. A total of 143 deep-sea sediment cores recovered from the North Atlantic Ocean were available for this purpose (Tables 1 and 2, Fig. 4, top left). The glacial summer SST was sampled from the gridded fields at the locations of the $\delta^{18} \mathrm{O}_{\mathrm{C}}$ cores and corrected to the calcification temperature $T_{C}$ of the foraminifera according to the following empirical relations:

Neogloboquadrina pachyderma sinistral

$\mathrm{T}_{\mathrm{C}}=\mathrm{SST}-2.5$

if $\mathrm{T}>4.5^{\circ} \mathrm{C}$

$\mathrm{T}_{\mathrm{C}}=0.42 \mathrm{SST}+0.39$

if $\mathrm{T}<4.5^{\circ} \mathrm{C}$

Weinelt (1993)

Globigerina bulloides

$\mathrm{T}_{\mathrm{C}}=\mathrm{SST}-1$

Duplessy et al. (1991)

$\delta^{18} \mathrm{O}_{\mathrm{w}}$ was then computed according to the Epstein et al. (1953) paleo-temperature equation:

$\delta^{18} \mathrm{O}_{\mathrm{W}}=\delta^{18} \mathrm{O}_{\mathrm{C}}-21.63+\left(310.61+10 \mathrm{~T}_{\mathrm{C}}\right)^{1 / 2}$,

with the carbonate and water oxygen isotope ratios expressed versus the PDB and SMOW standards, respectively. From $\delta^{18} \mathrm{O}_{\mathrm{w}}$, we calculated salinity at each sediment core location according to:

$\mathrm{S}=\Delta \mathrm{S}_{\mathrm{g}}+\mathrm{A}\left[\delta^{18} \mathrm{O}_{\mathrm{w}}-\Delta \delta^{18} \mathrm{O}_{\mathrm{g}}\right]+\mathrm{B}$,

where $\Delta \mathrm{S}_{\mathrm{g}}=1.07$ denotes the global salinity increase due to the lower glacial sea level and $\Delta \delta^{18} \mathrm{O}_{g}$ $=1.2$ represents the global increase of $\delta^{18} \mathrm{O}_{\mathrm{w}}$ due to the storage of ${ }^{16} \mathrm{O}$ in the continental ice sheets. To account for locally different relations between $\mathrm{S}$ and $\delta^{18} \mathrm{O}_{w}$, the coefficients A and B (Fig. 3) vary with latitude (Paul et al. 1999); they were derived from the Atlantic GEOSECS data (Östlund et al. 1987 ) as contained in the GISS $\delta^{18} \mathrm{O}$ database (Bigg and Rohling 2000; Schmidt et al. 1999). We used only the GEOSECS data for fitting because the complete $\delta^{18} \mathrm{O}_{\mathrm{w}}$ data set includes a large number of very low $\delta^{18} \mathrm{O}_{\mathrm{w}}$ and salinity values from the Labrador Sea that are not representative for most of the North Atlantic Ocean and would have considerably biased the result. We tried to use a $\delta^{18} \mathrm{O}_{\mathrm{w}}$ -salinity relation varying not only with latitude but also with season to account for the local effects of melting and formation of sea-ice, but the database was not sufficient to establish a relation for the boreal winter. Schmidt (1999) demonstrates that an incorrect $\delta^{18} \mathrm{O}_{\mathrm{w}}$-SSS relation does not significantly increase the salinity errors when salinity is high which is the case in the glacial northern North Atlantic. Furthermore, most of the high-latitude GEOSECS data were obtained during the warm season during which the foraminifera build up their shells, that is, both $\delta^{18} \mathrm{O}_{\mathrm{w}}$-SSS relation and $\delta^{18} \mathrm{O}_{\mathrm{w}}$ data can be in general attributed to the same time of the year. Therefore we adhered to the annual mean relation for our reconstructions.

Because the available $\delta^{18} \mathrm{O}_{\mathrm{C}}$ data span only a limited part of the northeastern Atlantic Ocean (Fig. 4, top left), it turned out to be difficult to incorporate the newly gridded data into whatever global data set without artificial gradients. Therefore, we gridded the glacial-to-modern salinity difference referenced to the $10-\mathrm{m}$-values of the WOA (1998) summer salinity, using the global 1.07 anomaly outside the data-covered region. The gridding was carried out by the same variogram analysis and kriging process that was employed for the temperature data. By adding the gridded anomaly field to the modern monthly salinity data (Schäfer-Neth and Paul 2001), these as well taken from the $10 \mathrm{~m}$ WOA (1998) analyses, we finally arrived at the seasonal SSS cycle (Fig. 4, bottom).

\section{SST and SSS Errors}

According to Malmgren et al. (2001), SST is reconstructed from the sediment cores with a statistical accuracy in the order of $1{ }^{\circ} \mathrm{C}$ by the modern analog techniques (MAT, SIMMAX), and with a slightly larger error of about $1.2^{\circ} \mathrm{C}$ by the transfer function (TF) approach. This is reflected by the SST differences of neighboring sediment cores (Fig. 1, top), even if the estimates were obtained with the 


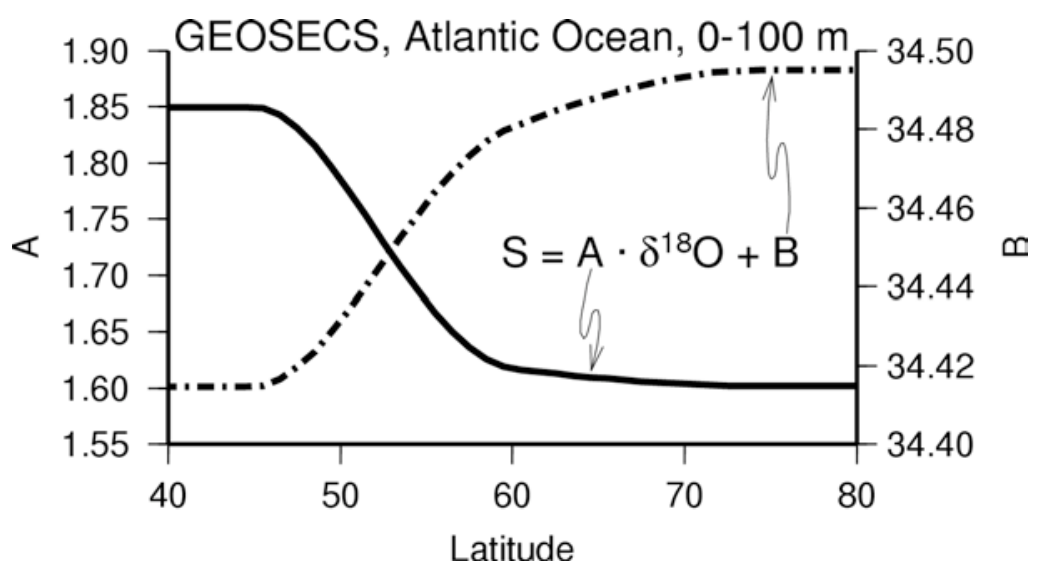

Fig. 3. Latitude-dependent linear fit between salinity and water oxygen isotopic composition obtained from the Atlantic Ocean's GEOSECS measurements.

same method. These differences in part exceed the $0.2^{\circ} \mathrm{C}$ error difference between MAT and $\mathrm{TF}$, and therefore we considered the latter as unimportant for our present study. In addition to the statistical uncertainties, there are a number of possible systematic errors: First, the depth habitats and the growing seasons of the foraminifera might have changed between LGM and present, such that the proxies might not as directly depend on sea surface conditions as MAT and TF assume. Both methods are calibrated to modern data and cannot account for these changes. Second, Malmgren et al. (2001) demonstrate that the inclusion of geographical information obtained from the modern training data might compromise the applicability of SIMMAX to climates very different from the modern. That is, SIMMAX could suffer from this error in regions where, for example, the LGM ocean currents differed from the modern ones. We regard the high northern latitudes of the Atlantic Ocean as most susceptible to this source of uncertainty because of the much larger glacial ice sheets. A comparative application of MAT and TF to the species countings from that region could yield more insight into this problem. However, this has not yet been done. Third, at the cold end of the SIMMAX data, there is a tendency of SST overestimation (Pflaumann et al. 2003) that may amount to more than $1^{\circ} \mathrm{C}$. We overcame this problem by including additional information on the position of the ice edges and setting SST to the freezing point in the ice-covered regions.

Thanks to the recent efforts in refining and standardizing and the acquisition of many new SST estimates, we could not discern any systematic trends or offsets between the contributions of the different research groups. Based on this, the dense spacing of the sediment cores, and the reasonable empirical variograms (Fig. 2), we regard our gridded SST fields as reliable pictures of the robust features at the surface of the Atlantic Ocean at the LGM.

Reconstructions of SSS are even more problematic because several sources of error are involved. To begin with the least important, there are the analytical errors of the parameters SSS is computed from: the SST uncertainty of about $1^{\circ} \mathrm{C}$ and the $\delta^{18} \mathrm{O}_{\mathrm{C}}$ measurement error of typically 0.1 . Error propagation through the application of the paleotemperature equation (2) yields a $\delta^{18} \mathrm{O}_{\mathrm{W}}$ error of about 0.4 , and, with the relation between $\delta^{18} \mathrm{O}_{\mathrm{W}}$ and salinity (3), an SSS error around 0.7. This is about $25 \%$ of the east-west and north-south contrasts of the reconstructed SSS anomalies in the subtropical and subpolar North Atlantic Ocean (Fig. 4, top left), that is, errors due to false SST and/or incorrect $\delta^{18} \mathrm{O}_{\mathrm{C}}$ would not change the salinity patterns very much, especially given the high spatial sampling density. Despite this fairly robust estimate of local SSS gradients we are left with a greater un- 


\section{Glacial Sea Surface Salinities}
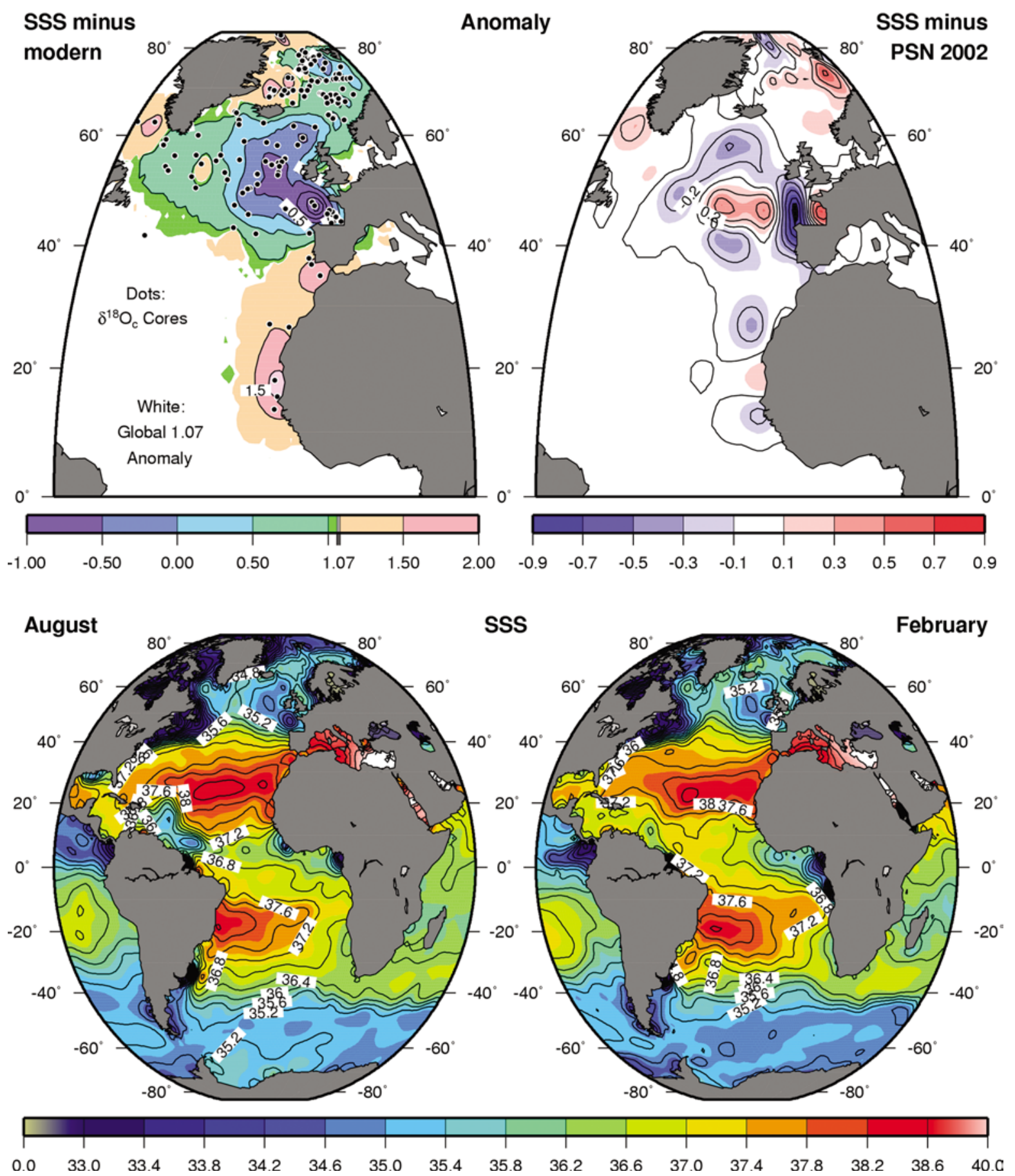

Fig. 4. Glacial sea-surface salinity. Top row: Glacial-to-modern anomaly (left) and difference between salinities based on sediment-core-SST and isoline-SST (right). Bottom row: Gridded seasonal fields. 
certainty introduced by the parameters of the empirical relationships between $\mathrm{SST}, \delta^{18} \mathrm{O}_{\mathrm{w}}, \delta^{18} \mathrm{O}_{\mathrm{C}}$, and SSS that affects the absolute salinity values. It turns out that the relation between $\delta^{18} \mathrm{O}_{\mathrm{W}}$ and salinity is less critical than the paleo-temperature equation (2) that basically links water temperature, water oxygen isotopic composition and the isotope ratio fixed in the carbonate shells of the foraminifera. Thus, Equation (2) is intimately tied to the life cycle of these organisms and varies depending on numerous parameters, such as the prevailing water masses during the season of reproduction and the water depth preferred by the different biota. Even for a single species, there may be different $\delta^{18} \mathrm{O}_{\mathrm{C}}$ values depending on when and where the samples were taken. For example, Mulitza et al. (this volume) report a systematic contrast of $1 \%$ between shells of Neogloboquadrina pachyderma sinistral that were sampled near the surface ocean (lighter values) and those retrieved from the core-top sediments (heavier due to secondary calcification), whereas there is no such offset for Globigerina bulloides. The temperature adjustments given by Equation (1) are just an attempt to compensate for these different offsets, and according to the review of different paleo-temperature calibrations by Bemis et al. (1998), SST adjustments of up to $4-5^{\circ} \mathrm{C}$ might be necessary, depending on the species, to yield a consistent $\delta^{18} \mathrm{O}_{\mathrm{w}}$ data set. Summarizing in a detailed analysis the influence of these effects on the reconstructed salinity, Schmidt (1999) estimates a total salinity error that may easily exceed 1 and reach even values around 1.8 in the tropics. A promising new approach in this respect is to set up an ecological model for the relationship between water $\delta^{18} \mathrm{O}_{\mathrm{w}}$ and foraminiferal $\delta^{18} \mathrm{O}_{\mathrm{C}}$ on a global scale, as proposed by Schmidt and Mulitza (2002) to quantify the vital effects based on temperature, depth habitat, and calcification processes. Presently, this model is in its initial stage and can not be directly applied to the glacial chronozone for deducing water isotopic composition from the carbonate $\delta^{18} \mathrm{O}_{\mathrm{C}}$ data (Schmidt pers. comm. 2002). Ideally, such a model should be combined with a global set of glacial $\delta^{18} \mathrm{O}_{\mathrm{C}}$ measurements presently under preparation (Mulitza et al. this volume). For the moment we can only test the effects of reconstructed
SST and regional SSS by numerical model experiments and assess the reconstructions with regard to the resulting water mass and circulation patterns. In our earlier publication (PSN), we therefore considered different additional salinity offsets in the Southern Ocean and their interplay with the reconstructed SSS in the North Atlantic Ocean. Despite all uncertainties of the individual SSS reconstructions, we gain confidence in the overall LGM SSS patterns from the results of recent coupled atmosphere-ocean models. For example, Shin et al. (2003) find local glacial anomalies in the range of our reconstructions. Especially the pattern of anomalies in excess of the global shift in the northwestern Atlantic Ocean and lower than the global shift near the Gulf of Biscay (Fig. 4) is well met in their model, which does not rely on any SST or SSS reconstruction.

\section{Availability}

The gridded $1^{\circ} \times 1^{\circ} \mathrm{SST}$ and SSS data are available from the World Data Center for Paleoclimatology, 325 Broadway, Boulder, Colorado; http:// www.ngdc.noaa.gov/paleo/paleo.html; email: paleo@noaa.gov

\section{Comparison to CLIMAP}

\section{Core-Based and CLIMAP SST}

When comparing the newly gridded SST and the CLIMAP reconstruction (Fig. 5, top), the mostprominent feature is that the new data turns out to be generally colder than CLIMAP in the low and mid latitudes but is distinctly warmer in the high latitudes, especially during the summer season.

The lower SST is consistent with the lower temperature based on other proxy data evidence that were discussed by Prell (1985), Guilderson et al. (1994), and Crowley (2000). A glacial Atlantic Ocean cooler than CLIMAP is as well supported by reconstructed land temperatures in eastern North America (Aeschbach-Hertig et al. 2000) and in tropical America (Aeschbach-Hertig et al. 2002; Rind and Peteet 1985; Stute et al. 1995), although indirectly. Only in a narrow band in the tropical 


\section{GLAMAP minus CLIMAP SST}
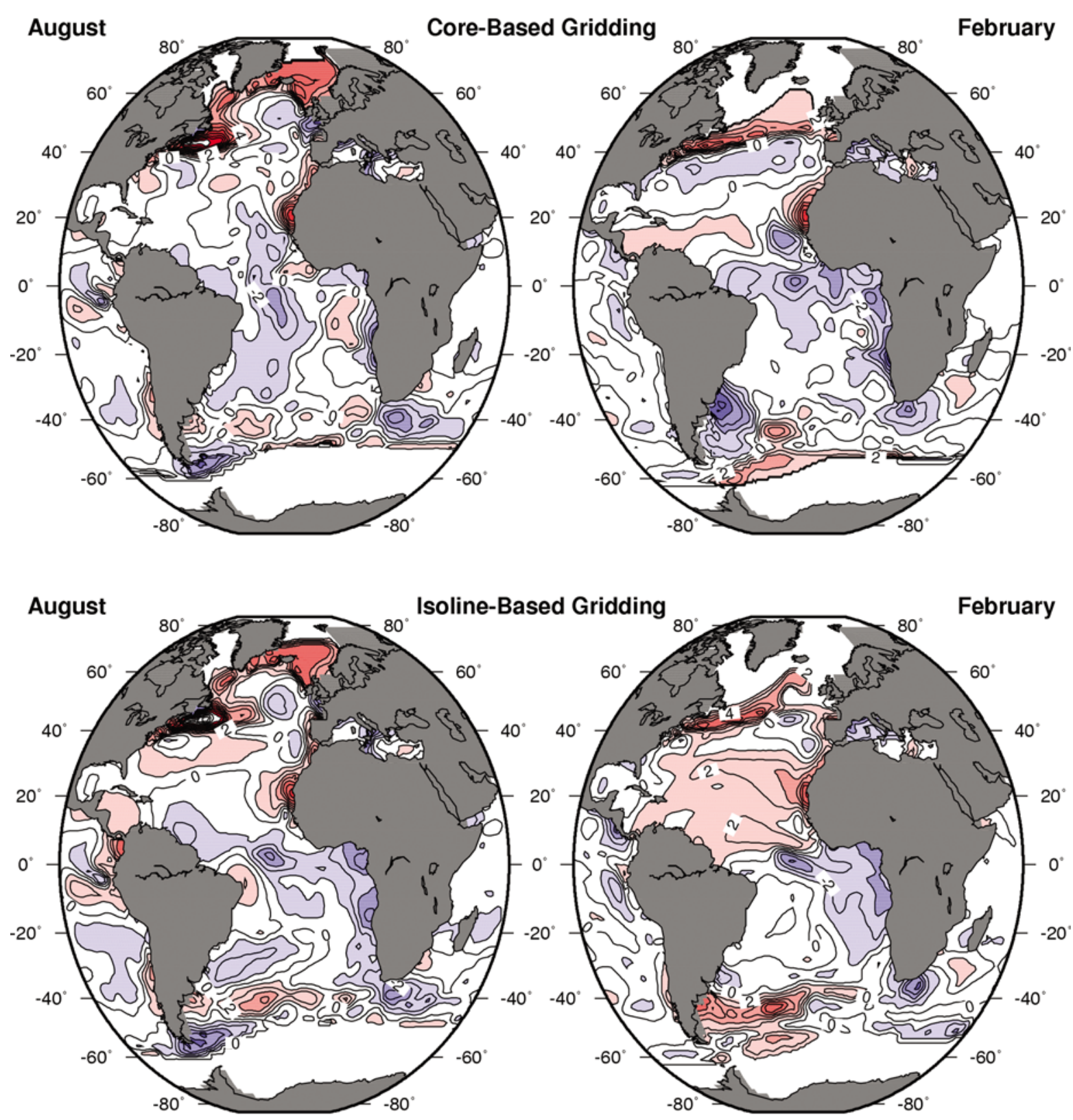

.

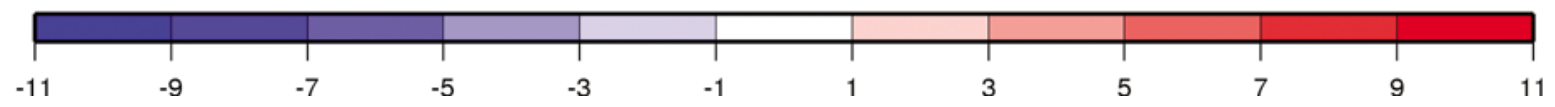

Fig. 5. Differences between the new GLAMAP and the CLIMAP (1981) reconstruction. Top row: Objectively interpolated from the sediment core-based reconstructions. Bottom row: Gridded using the digitized isolines by Pflaumann et al. (2002). 
North Atlantic Ocean during February, the new data turned out to be warmer than the CLIMAP reconstruction. This band is supported by numerous sediment cores from different institutions (Fig. 1, top right). Thus the new data set is in good agreement with the modest glacial cooling of $2-2.5^{\circ} \mathrm{C}$ in the tropics that has been suggested by Crowley (2000) based on his review of the different available SST proxies. According to Hostetler and Mix (1999) and Mix et al. (1999), the tropical cooling was most pronounced in the eastern parts of the oceans where the eastern boundary currents interact with the equatorial circulation. This eastwest gradient of glacial cooling is well represented in the core-based temperature fields. The glacialto-modern anomalies increase from values around $2{ }^{\circ} \mathrm{C}$ in the western equatorial Atlantic Ocean to values around $5^{\circ} \mathrm{C}$ in the eastern (not shown here).

The increase of SSTs relative to CLIMAP in the high latitudes is simply caused by the higher seasonality of the new ice cover reconstruction, yielding less ice in summer and as well in winter. The ice-free Nordic Seas are not only supported by the faunal assemblages underlying the present compilation but by temperature reconstructions from alkenone concentrations, too (Rosell-Melé 1997; Rosell-Melé and Comes 1999). There is a small area warmer than CLIMAP in both seasons at about $50^{\circ} \mathrm{S} / 40^{\circ} \mathrm{W}$ which is in an area where no SST estimates are available (Fig. 1, top). We regard this feature as an artifact.

Along the coast of Africa, there are several smaller regions that indicate an SST differing from CLIMAP, in most cases lower, in some cases higher. These are related to the upwelling regions of the eastern Atlantic Ocean and the water masses transported by the Benguela current that are much better resolved and more detailed in the new GLAMAP data set than in CLIMAP. According to recent modeling results of PSN and Paul and Schäfer-Neth (2003), these characteristics indicate changed properties of the upwelled waters, but no distinctly different upwelling rates.

The intense lowering of SSTs in the Argentine Basin in February is linked to a single sediment core (Fig. 1, top) and needs perhaps further investigation.

\section{Isoline-Based and CLIMAP SST}

In contrast to the core-based reconstruction, the gridded field derived from the isolines exhibits markedly higher SST than CLIMAP, especially in the tropical and subtropical North Atlantic Ocean and along approximately $40^{\circ} \mathrm{S}$ during boreal winter, clearly in contrast to other proxy data evidence (Crowley 2000). We identified two main causes for this. First, in latitudes higher than $15^{\circ}$ (both hemispheres), the isolines seem to be drawn too far poleward with respect to the core data, which causes the large negative anomaly between the core- and isoline-based grids around $30^{\circ} \mathrm{N}$ in February (Fig. 6, right). Likewise, the negative anomaly at about $10^{\circ} \mathrm{S}$ in August (Fig. 6, left) can be attributed to an eastward shift of the isolines. However, it must be noted that we did not find a true mismatch between the core data and the handdrawn isolines: the shift of the isolines is most prominent in regions where there are large distances between the sediment cores, leaving several possibilities for 'true' interpolating lines. Second, the $26^{\circ} \mathrm{C}$ and $27^{\circ} \mathrm{C}$ isolines for February enclose an area of cores indicating generally lower temperatures, but some actually showing precisely these values. In this case, the cores are densely spaced but show widely different temperatures, and drawing the isolines is a matter of judging some cores as more reliable than others. Again, the researcher is left with a good deal of freedom. As a result, the isoline-based SST exceeds the corebased by more than $3^{\circ} \mathrm{C}$ northeast of northern Brazil (Fig. 6, right). A possible reason for this bias towards higher SST values in the isoline reconstruction might be the fact that the isolines were constructed for the GLAMAP chronozone, which in general is somewhat warmer than EPILOG (Gersonde et al. 2003). Unfortunately, no EPILOG version of the isolines was available for our study.

The strong positive anomaly relative to CLIMAP in the Argentine Basin (Fig. 5, lower right) indicates another problem related to the isoline reconstruction. In order to avoid unrealistic zonal gradients in the gridded SST field, we had (PSN) to extend the isolines by additional tie points into an area with almost no sediment cores (Fig. 1, top). As in the case of the hand-drawn isolines in areas 


\section{Core-Based minus Isoline-Based SST}
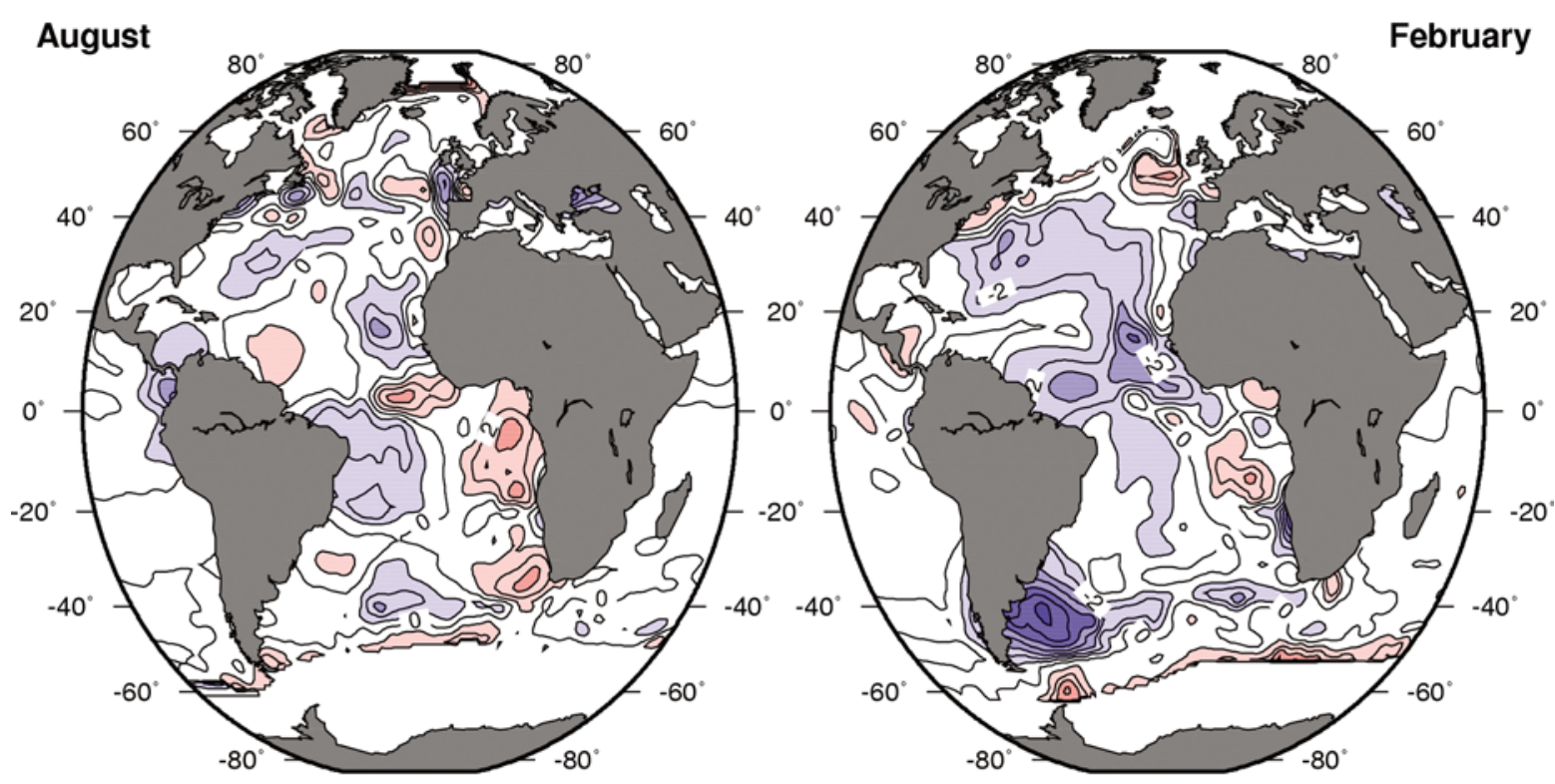

${ }^{\circ} \mathrm{C}$

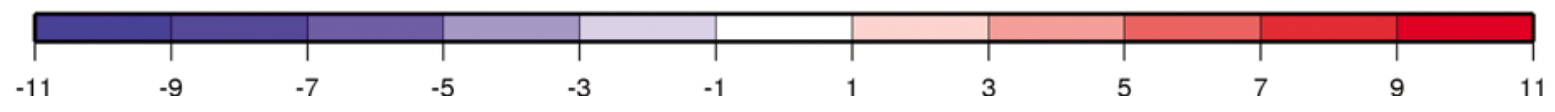

Fig. 6. Differences between the sediment core-based SST reconstruction and the isoline-based.

of sparse data, the position of these tie points is arbitrary to some extent, and moving the points could either diminish or enhance the anomaly.

\section{SSS Differences between Isoline-Based and Core-Based SST Reconstructions}

Except for a small region west of Ireland, the new SST field yields lower salinities than we reconstructed in our previous study (Fig. 4, top right). However, these changes are smaller than the accuracy of the SSS reconstruction and limited to the northeastern part of the Atlantic Ocean, so that we will focus on the SST differences that extend over almost the entire Atlantic Ocean.

\section{Model Experiments}

To further investigate the differences between the two LGM SST reconstructions, we performed a number of experiments with a numerical ocean circulation model that are described in detail in our accompanying publication (Paul and Schäfer-Neth 2003).

For the present study, we compare three model experiments: A control run that was driven by present-day boundary conditions, and two runs forced by the core-based and isoline-based glacial SST fields. The wind stress fields for the model experiments were derived from the control run of the European Centre/Hamburg atmospheric general circulation model (ECHAM3) at T42 resolution and a run that employed the isoline-based gridded SST field as bottom boundary condition (Lorenz and Lohmann, pers. comm.; for a more detailed discussion, see PSN). Both glacial model runs discussed here were driven with this wind field, which in this context allows us to highlight the effect of the different thermohaline boundary conditions. 
Figure 7 displays the modeled glacial-to-modern temperature changes along a section through the western Atlantic Ocean. Both glacial runs show a marked cooling of the deep convection area in the northern North Atlantic Ocean as well as of the thermocline waters in low and mid-latitudes. In the run forced by the core-based SST, the low-latitude cooling is much more pronounced than in the run forced by the isoline-based temperature. This corresponds well to the findings of Slowey and Curry
(1995) from the western Bahama Banks, who propose a temperature shift of around $4{ }^{\circ} \mathrm{C}$ for the upper $1000 \mathrm{~m}$, and of Curry et al. (1999), who reconstruct a cooling of $4-6^{\circ} \mathrm{C}$ at $60^{\circ} \mathrm{N}$. Thus, the model results suggest that the core-based SST field is more consistent with the reconstructed meridional structure of the glacial thermocline than the isoline-based SST field.

In their coupled atmosphere-ocean model experiment, Liu et al. (2002) reproduce a similar cool-
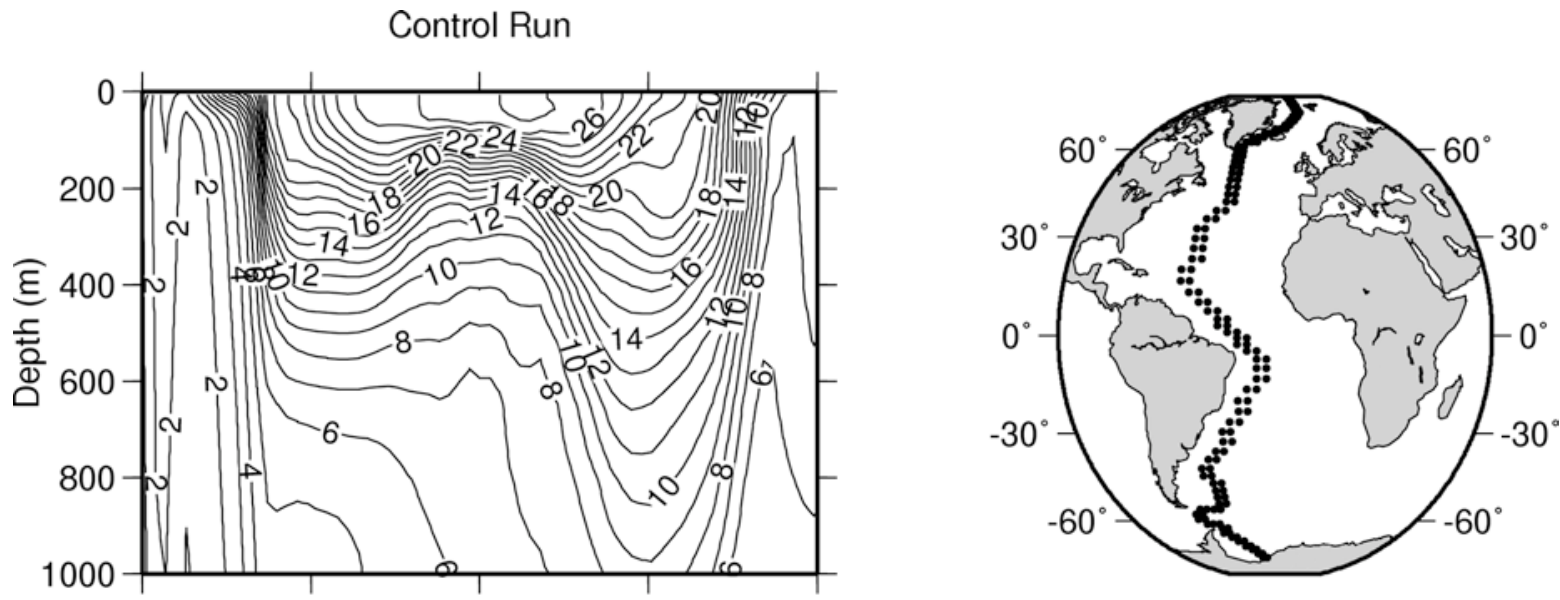

Isoline-Based minus Control

Core-Based minus Control

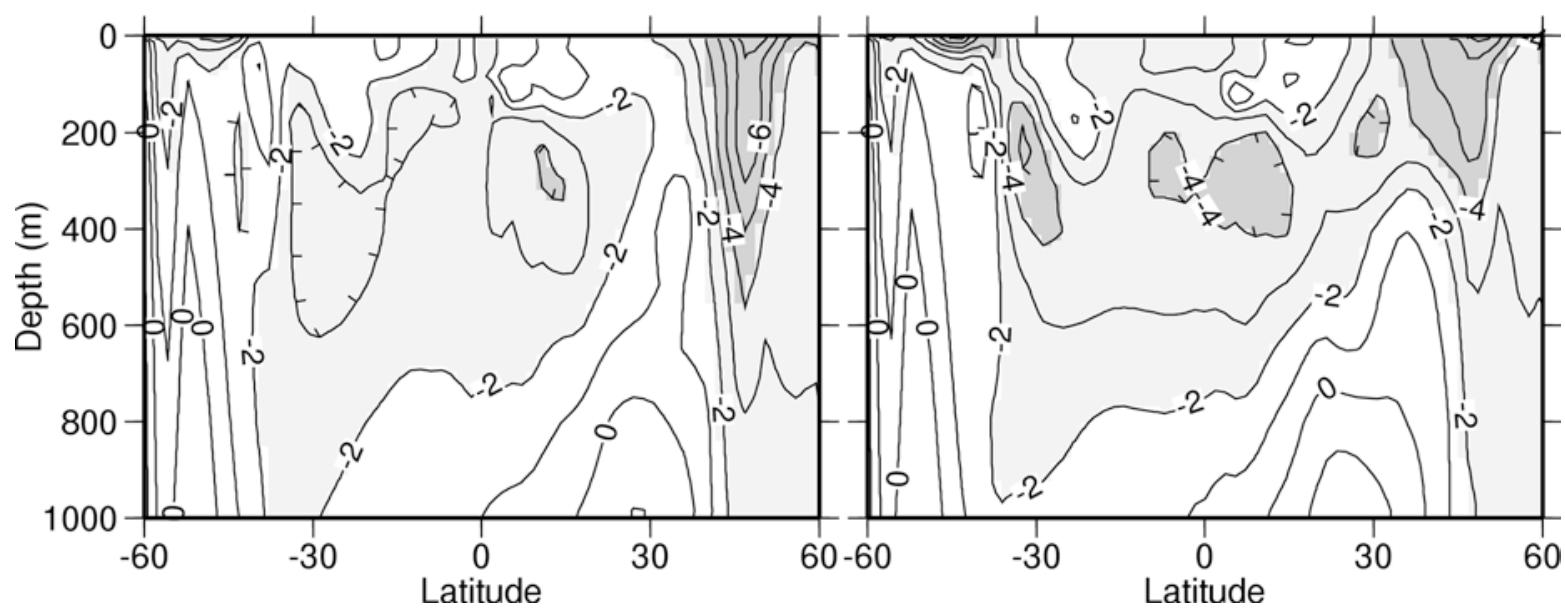

Fig. 7. Modeled temperatures along a section following GEOSECS (top right) through the western Atlantic Ocean. Top: Control run under present-day forcing. Bottom: Differences between the LGM and control runs. Left: LGM run driven by the isoline-based SST reconstruction, right: LGM experiment forced with the core-based SST fields. Light grey: below $-2^{\circ} \mathrm{C}$, dark grey: below $-4^{\circ} \mathrm{C}$. 
ing signature, not only for the northern hemisphere, but as well for the South Atlantic Ocean.

\section{Summary}

- Based on new sediment-core-based SST estimates, we constructed objectively interpolated data sets of February and August SST for the whole Atlantic Ocean.

- These fields were incorporated into the global CLIMAP data set, and a seasonal cycle for every month was constructed according to the PMIP approach.

- Judging from (i) a direct comparison of these data with an earlier set based on a subjective interpolation, (ii) a comparison of both fields with CLIMAP and other paleo-SST evidence, and (iii) the outcome of two experiments with a general ocean circulation model, we regard the objectively interpolated fields as more reliable.

\section{Acknowledgements}

We wish to thank S. Mulitza for his help with the application of the different available paleo-temperature equations and the interpretation of the numerous species-dependent relations between temperature and oxygen isotopes. Our paper benefited from the comments of $\mathrm{M}$. Weinelt and an anonymous referee, which we gratefully acknowledge. This research was funded by the Deutsche Forschungsgemeinschaft (DFG) as part of the Sonderforschungsbereich 261, No. 375, and the DFG Research Center "Ocean Margins" of the University of Bremen, No. RCOM 0082.

\section{References}

Abelmann A, Brathauer U, Gersonde R, Sieger R, Zielinski U (1999) Radiolarian-based transfer function for the estimation of sea surface temperatures in the Southern Ocean (Atlantic sector). Paleoceanography 14: 410-421

Aeschbach-Hertig W, Peeters F, Beyerle U, Kipfer R (2000) Palaeotemperature reconstruction from noble gases in ground water taking into account equilibration with entrapped air. Nature 405: 1040-1044

Aeschbach-Hertig W, Stute M, Clark JF, Reuter RF, Schlosser P (2002) A paleotemperature record derived from dissolved noble gases in groundwater of the Aquia Aquifer (Maryland, USA). Geochim Cosmochim Acta 66: 797-817

Bard E, Arnold, M, Maurice P, Duprat J, Duplessy J-C (1987) Retreat velocity of the North Atlantic polar front during the last deglaciation determined by ${ }^{14} \mathrm{C}$ accelerator mass spectrometry. Nature 328: 791-794

Bemis BE, Spero HJ, Bijma J, Lea DW (1998) Reevaluation of the oxygen isotopic composition of planktonic foraminifera: Experimental results and revised paleotemperature equations. Paleoceanography 13: $150-160$

Bigg GR (1994) An ocean general circulation model view of the glacial Mediterranean thermohaline circulation. Paleoceanography 9: 705-722

Bigg GR, Rohling EJ (2000) An oxygen isotope data set for marine water. J Geophys Res 105: 8527-8535

CLIMAP Project Members (1981) Seasonal reconstructions of the Earth's surface at the Last Glacial Maximum. Geological Society of America, Map and Chart Series MC-36, $18 \mathrm{p}$

Crosta X, Pichon JJ, Burckle L (1998) Application of modern analog technique to marine Antarctic diatoms: reconstruction of maximum sea-ice extent at the last glacial maximum. Paleoceanography 13: 284297

Crowley T (2000) CLIMAP SSTs re-revisited. Clim Dyn 16:241-255

Curry WB, Marchitto TM, McManus JF, Oppo DW, Laarkamp KL (1999) Millennial-scale changes in ventilation of the thermocline, intermediate, and deep waters of the glacial North Atlantic. In: Clark PU, Webb RS, Keigwin LD (eds) Mechanisms of Global Climate Change at Millennial Time Scales. Geophysical Monograph Series, Vol 112, pp 59-76

De Vernal A, Hillaire-Marcel C, Turon J-L, Matthiesen J (2000) Reconstruction of sea-surface temperature, salinity and sea ice cover in the northern North Atlantic during the Last Glacial Maximum based on dinocyst assemblages. Canadian J Earth Sci 37: 725750

Deutsch CV, Journel AG (1992) GSLIB, Geostatistical Software Library and User's Guide. Oxford University Press, New York, Oxford

Duplessy J-C, Labeyrie L, Arnold M, Paterne M, Duprat J, van Weering TCE (1992) Changes in surface salinity of the North Atlantic during the last deglaciation. Nature 358: 485-488

Duplessy J-C, Labeyrie L, Juillet-Leclerc A, Maitre F, Duprat J, Sarnthein M (1991) Surface salinity reconstruction of the North Atlantic Ocean during the last glacial maximum. Oceanol Acta 14:311-324 
Duplessy J-C, Labeyrie L, Paterne M, Hovine S, Fichefet T, Duprat J, Labracherie M(1996) High Latitude Deep Water Sources During the Last Glacial Maximum and the Intensity of the Global Oceanic Circulation. In: Wefer G, Berger WH, Siedler G, Webb DJ (eds) The South Atlantic: Present and Past Circulation. Springer, Berlin, pp 445-460

Epstein S, Buchsbaum R, Lowenstam HA, Urey HC (1953) Revised carbonate-water isotopic temperature scale. Geol Soc Am Bull 64: 1315-1325

Gersonde R, Abelmann A, Brathauer U, Cortese G, Fütterer D, Grobe H, Niebler H-S, Segl M, Sieger R, Zielinski U (2003) Last Glacial Maximum sea surface temperature and sea ice extent in the Southern Ocean (Atlantic-Indian sector): A multiproxy approach. Paleoceanography 18: doi: 10.10292002PA000809

Gersonde R, Zielinski U (2000) The reconstruction of late Quaternary Antarctic sea-ice distribution-the use of diatoms as proxies for sea-ice. Paleogeogr Paleoclimatol Paleoecol 162: 263-286

Guilderson TP, Fairbanks RG, Rubenstone JL (1994) Tropical temperature variations since 20,000 years ago: Modulating interhemispheric climate change. Science 263: 663-664

Hostetler SW, Mix AC (1999) Reassessment of ice-age cooling of the tropical ocean and atmosphere. Nature 399: 673-676

Jansen E, Erlenkeuser HH (1985) Ocean circulation in the Norwegian Sea 15000 bp to present. Boreas 14: 189206

Jansen E, Veum T (1990) Evidence for two-step deglaciation and its impact on North Atlantic deep water circulation. Nature 343: 612-616

Jones GA, Keigwin LD (1989) Evidence from FRAM Strait $\left(78^{\circ} \mathrm{N}\right)$ for early deglaciation. Nature 336 : 5659

Jünger B (1993) Tiefenwassererneuerung in der Grönlandsee während der letzten 340000 Jahre. GEOMAR Report No. 35, Kiel Germany 103 p

Keigwin LD, Boyle EA (1989) Late Quaternary chemistry of high-latitude surface waters. Paleogeogr Paleoclimatol Paleoecol 3: 85-106

Kellogg TB, Duplessy J-C, Shackleton NN (1978) Planctonic foraminiferal and oxygen isotopic stratigraphy and paleoclimatology of Norwegian deep-sea cores. Boreas 7: 61-73

Köhler, SEI (1991) Spärtquartäre paläo-ozeanographische Entwicklung des Nordpolarmeers anhand von Sauerstoff- und Kohlenstoffisotopenverhältnissen der planktischen Foraminifere Neogloboquadrina pachyderma ( $\sin$ ). GEOMAR Report No. 13, Kiel, Germany, $104 \mathrm{p}$
Lackschewitz KS (1991) Sedimentationsprozesse am aktiven mittelatlantischen Kolbinsey Rücken (nördlich von Island). GEOMAR Report No. 9, Kiel Germany $121 \mathrm{p}$

Levitus S (1982) Climatological atlas of the World Ocean. NOAA Prof. Paper No. 13, $173 \mathrm{p}$

Levitus S, Boyer TP (1994) World Ocean Atlas. Volume 4: Temperature. NOAAAtlas NESDIS No. 4, $117 \mathrm{p}$

Liu Z, Shin S, Otto-Bliesner B, Kutzbach JE, Brady EC, Lee D (2002) Tropical cooling at the last glacial maximum and extratropical ocean ventilation. Geophys Res Lett 29: doi: 10.1029/2001GL013938

Malmgren BA, Kucera M, Waelbroeck C, Nyberg J (2001) Comparison of statistical and artificial neural network techniques for estimating past sea-surface temperatures from planktonic foraminifer census data. Paleoceanography 16: 520-530

Melles M (1991) Late Quaternary paleoglaciology and paleoceanography at the continental margin of the southern Weddell Sea, Antarctica. Berichte zur Polarforschung. Bremerhaven Vol 81, Alfred-WegenerInstitut für Polar- und Meeresforschung, Bremerhaven, Germany

Mix AC, Bard E, Schneider R (2001) Environmental processes of the ice age: Land, oceans, glaciers (EPILOG) Quat Sci Rev 20: 627-658

Mix AC, Morey AE, Pisias NG, Hostetler SW (1999) Foraminiferal faunal estimates of paleotemperature: Circumventing the no-analog problem yields cool ice age tropics. Paleoceanography 14: 350-359

Morris TH (1988) Stable isotope stratigraphy of the Arctic Ocean: Fram Strait to Central Arctic. Paleogeogr Paleoclimatol Paleoecol 64: 201-219

Niebler H-S, Gersonde R (1998) A planktic foraminiferal transfer function for the southern South Atlantic Ocean. Mar Micropaleontol 34: 213-234

Niebler H-S, Mulitza S, Donner B, Arz H, Pätzold J, Wefer G (2003) Sea-surface temperatures in the equatorial and South Atlantic Ocean during the Last Glacial Maximum (23-19 ka). Paleoceanography 18: doi: 10.1029/2002PA000902

Östlund H, Craig H, Broecker WS, Spencer D (1987) Geosecs Atlantic, Pacific, Indian Ocean expeditions. shorebased data and graphics. GEOSECS Atlas Series Vol. 7, US Government Printing Office, Washington, DC

Paul A, Mulitza S, Pätzold J, Wolff T (1999) Simulation of oxygen isotopes in a global ocean model. In: Fischer G, Wefer G (eds) Use of Proxies in Paleoceanography: Examples from the South Atlantic. Springer, Berlin, pp 655-686

Paul A, Schäfer-Neth C (2003) Modeling the water 
masses of the Atlantic Ocean at the Last Glacial Maximum. Paleoceanography 18: doi: 10.1029/ 2002PA 000783

Pflaumann U, Duprat J, Pujol C, Labeyrie LD (1996) SIMMAX: A modern analog technique to deduce Atlantic sea surface temperatures from planktonic foraminifera in deep-sea sediments. Paleoceanography 11: 15-35

Pflaumann U, Sarnthein M, Chapman M, Funnel B, Huels M, Kiefer T, Maslin M, Schulz H, Swallow J, van Kreveld S, Vautravers M, Vogelsang E, Weinelt M (2003) The Glacial North Atlantic: Sea-surface conditions reconstructed by GLAMAP-2000. Paleoceanography 18: doi: 10.1029/2002PA000774

PMIP (1993) Paleoclimate modelling intercomparison project, http://www-pcmdi.llnl.gov/pmip/newsletters/newsletter02.html. Technical report

Prell WL (1985) The stability of low latitude sea surface temperature. An evaluation of the CLIMAP reconstruction with emphasis on the positive SST anomalies. Technical report, Department of Energy, Washington, DC

Rind D, Peteet D (1985) Terrestrial conditions at the last glacial maximum and climap sea-surface temperature estimates: Are they consistent? Quat Res 24: 1-22

Rosell-Melé A (1997) Appraisal of climap temperature reconstruction in the NE Atlantic using alkenone proxies. EOS 78: F28

Rosell-Melé A, Comes P (1999) Evidence for a warm last glacial maximum in the nordic seas, or an example of shorthcomings in UK37' and UK37 to estimate low sea surface temperature? Paleoceanography 13: 694-703

Ruddiman WF, McIntyre AA(1981) The North Atlantic during the last deglaciation. Paleogeogr Paleoclimatol Paleoecol 35: 145-214

Rühlemann C, Mulitza S, Müller PJ, Wefer G, Zahn R (1999) Warming of the tropical Atlantic Ocean and slowdown of thermohaline circulation during the last deglaciation. Nature 402: 511-514

Sarnthein M, Gersonde R, Niebler H-S, Pflaumann U, Spielhagen R, Thiede J, Wefer G, Weinelt M (2003a) Overview of Glacial atlantic ocean mapping (GLAMAP-2000) Paleoceanography 18: doi: 10.1029/ 2002 PA00769.

Sarnthein M, Jansen E, Weinelt M, Arnold M, Duplessy J-C, Erlenkeuser H, Flatøy A, Johannessen G, Johannessen T, Jung S, Koç N, Labeyrie L, Maslin M, Pflaumann U, Schulz H (1995) Variations in Atlantic surface ocean paleoceanography, $50^{\circ}-80^{\circ} \mathrm{N}$ : A time-slice record of the last 30,000 years. Paleoceanography 10: 1063-1094
Sarnthein M, Pflaumann U, Weinelt M (2003b) Past extent of sea ice in the northern North Atlantic inferred from foraminiferal paleotemperature estimates. Paleoceanography 18: doi: 10.1029/2002PA000771

Schäfer-Neth C (1998) Changes in the seawater-oxygen isotope relation between last glacial and present: Sediment core data and OGCM modelling. Paleoclimatology 2: 101-131

Schäfer-Neth C, Hervada-Sala C, Pawlowsky-Glahn V, Stattegger K (1998) Geostatistical interpretation of paleoceanographic data over large ocean basins reality and fiction. In: Buccianti A, Nardi G, Potenza R (eds) Proceedings of the Fourth Annual Conference of the International Association for Mathematical Geology. De Frede, Napoli, Italy, pp 111-116

Schäfer-Neth C, Paul A (2001) Circulation of the glacial Atlantic: A synthesis of global and regional modeling. In: Schäfer P, Ritzrau W, Schlüter M, Thiede J (eds) The northern North Atlantic: A changing environment. Springer, Berlin, pp 441-462

Schmidt GA (1999) Error analysis of paleosalinity calculations. Paleoceanography 14: 422-429

Schmidt GA, Bigg GR, Rohling EJ (1999) Global seawater oxygen-18 database. http://www.giss.nasa.gov/ data/o18data Technical report, Goddard Institute for Space Studies

Schmidt GA, Mulitza S (2002) Global calibration of ecological models for planktic foraminifera from coretop carbonate oxygen-18. Mar Micropalaentol 44: 125140

Schulz H (1994) Meeresoberflächentemperaturen im frühen Holozän 10,000 Jahre vor heute. Dissertation, Universität Kiel, Germany

Shin, S, Liu Z, Otto-Bliesner O, Brady EC, Kutzbach JE, Harrison SP (2003) A simulation of the Last Glacial Maximum Climate using the NCAR-CCSM. Clim Dyn 20: $127-151$

Slowey NC, Curry WB (1995) Glacial-interglacial differences in circulation and carbon cycling within the upper western North Atlantic. Paleoceanography 10: 715-732

Stute M, Forster M, Frischkorn H, Serejo F, Clark A, Schlosser P, Broecker WS, Bonani G (1995) Cooling of tropical Brazil $\left(5^{\circ} \mathrm{C}\right)$ during the Last Glacial Maximum. Science 269:379-383

Stute M, Schlosser P, Clark JF, Broecker WS (1992) Paleotemperatures in the southwestern United States derived from noble gas measurements in groundwater. Science 256: 1000-1003

Thiede J (1978) A glacial Mediterranean. Nature 276: $680-683$

Thunell RC (1979) Eastern Mediterranean sea during the 
Last Glacial Maximum; an 18,000-years BP reconstruction. Quat Res 11:353-372

Veum T, Arnold M, Beyer I, Duplessy J-C (1992) Water mass exchange between the North Atlantic and the Norwegian Sea during the last 28000 years. Nature 356: 783-785

Vogelsang E (1990) Paläo-Ozeanographie des Europäischen Nordmeers an Hand stabiler Kohlenstoffund Sauerstoffisotopen. Berichte aus dem Sonderforschungsbereich 313 der Universität Kiel No. 23, University Kiel, Germany, $136 \mathrm{p}$

Weinelt M (1993) Veränderungen der Oberflächenzirkulation im Europäischen Nordmeer während der letzten 60,000 Jahre-Hinweise aus stabilen Isotopen. Berichte aus dem Sonderforschungsbereich 313 der Universität Kiel No. 41, University Kiel, Germany,
$105 \mathrm{p}$

Weinelt M, Sarnthein M, Pflaumann U, Schulz H, Jung $S$, Erlenkeuser H (1996) Ice-free Nordic Seas during the Last Glacial Maximum? Potential sites of deepwater formation. Paleoclimatology 1:283-309

WOA (1998) World ocean atlas 1998, http:// www.nodc.noaa.gov/oc5/woa98.html. Technical report, National Oceanographic Data Center, Silver Spring, Maryland

Zahn R, Markussen B, Thiede J (1985) Stable isotope data and depositional environments in the Late Quaternary. Nature 314: 433-435

Zielinski U, Gersonde R, Sieger R, Fütterer D (1998) Quaternary surface water temperature estimations: Calibration of a diatom transfer function for the Southern Ocean. Paleoceanography 13: 365-383 